This is an Open Access article, distributed under the terms of the Creative Commons Attribution licence (http://creativecommons.org/licenses/by/4.o/), which permits unrestricted re-use, distribution, and reproduction in any medium, provided the original work is properly cited. doi:10.1017/So144686X17000873

\title{
Household changes and diversity in housing consumption at older ages in Scotland
}

\author{
FRANCESCA FIORI*, ELSPETH GRAHAM $\dagger$ and \\ ZHIQIANG FENG +
}

\begin{abstract}
This paper contributes to understanding housing adjustments in later life by investigating the role of four key lifecourse transitions experienced by older individuals and their households, namely changes in health, retirement, union transitions and adult children leaving the household. Using data from a representative sample of the Scottish population for the decade 2001-2011, the study examines who moves and, for movers, whether they adjust their housing size in response to changes in their personal and household circumstances. In particular, the study explores diversity in housing consumption at older ages by investigating whether the triggers of upsizing or downsizing differ across tenure groups. The majority of older adults in Scotland do not change their place of residence during the study decade. For the minority who do move, all four lifecourse transitions are significant triggers for residential relocation but there is considerable diversity across the two major tenure groups in the influence of household changes on their housing consumption adjustments. In both tenure groups, however, the presence of children in the household is associated with upsizing and is a significant impediment to downsizing. Given the relative rootedness of older parents with co-resident adult children and their propensity to upsize rather than downsize if they move, our findings raise concerns over the interdependencies between younger and older generations in the housing market.
\end{abstract}

KEY WORDS-household changes, residential moves, housing adjustments, downsizing, upsizing, older adults, Scotland.

* ESRC Centre for Population Change, School of Geography \& Sustainable Development, University of St Andrews, UK.

$\dagger$ ESRC Centre for Population Change, School of Geography \& Sustainable Development, University of St Andrews, UK.

$\$$ ESRC Centre for Population Change, School of Geosciences, University of Edinburgh, UK. 


\section{Introduction}

The generation that reached adulthood in the $195^{\text {os }}$ and early 1960 s entered retirement in the two decades around the turn of the millennium. Compared to their parent's generation, on average they are wealthier, living longer and more likely to own their own home. Significant demographic, social and economic changes over their lifetime may also have resulted in increased diversity across individual lifecourses and housing careers. Smaller families, rising divorce rates, re-partnering and longer healthy life expectancy have all challenged the idea of marital and housing stability for the greater part of adult life. Further, the housing boom and bust of the last decade and the recent economic downturn have prompted growing attention from policy makers in Britain to issues of intergenerational justice and, some argue, the need for older adults to downsize in order to release family housing for the younger generation. The study of residential relocation and housing consumption at older ages thus represents an important focus for research.

Empirical studies within the British context have provided some support for an early conceptualisation of migration at older ages as a response to major lifecourse transitions, such as retirement initially, and later the deterioration in health (Litwak and Longino 1987). However, they have also highlighted other household changes-such as widowhood-that are increasingly acting as important triggers of both residential moves and adjustments in housing consumption (Glaser and Grundy 1998; Uren and Goldring 2007). More generally, contemporary re-theorisations of residential mobility (Geist and McManus 2008; Findlay et al. 2015; Mulder and Hooimeijer 1999) and housing transitions (Beer and Faulkner 2011) have come to recognise the variety of family forms and the growing complexity of family trajectories. One implication of this body of work is that certain household changes may be more, or less, important for different groups in the population, and that this will be reflected in the diversity of mobility and housing pathways among individuals. Although there is a growing literature on residential mobility at older ages in Britain, few studies compare different housing tenure groups or include Scotland in their empirical investigations in spite of its more rapidly ageing population, a different housing stock and a distinctive policy environment compared with the rest of the United Kingdom (UK).

The current study aims to fill this research gap and extend understanding of lifecourse diversity by investigating residential mobility and housing transitions at older ages in Scotland. It focuses on adults aged $55^{-69}$ and follows them over a decade, thus covering the life phase when they are typically experiencing important changes in their households' characteristics and 
composition. Drawing on data from the Scottish Longitudinal Study (Boyle et al. 2009) for the decade 2001-2011, it investigates the role of household changes at older ages in triggering adjustments of housing size for those who undertake residential moves. The study expands the scope of much previous research by considering individuals within their household context and including not only retirement but also other important lifecourse transitions at older ages, such as the departure of children from the family home and union (partnership) transitions. Further, it places emphasis on the role of changes in personal and household circumstances, both as triggers to residential moves, and as drivers of downsizing or upsizing housing. In particular, the study seeks to explore diversity in housing consumption at older ages by examining whether the main triggers of upsizing or downsizing housing differ across tenure groups.

\section{Residential moves and housing adjustments at older ages}

The notion that individuals move geographically and adjust their housing as a functional response to changing personal and household circumstances is not new within academic literature on mobility (Rossi 1955) and housing (Forrest 1987; Kendig 1984; Payne and Payne 1977; Pickvance 1974). Implicit in this early work, however, was the assumption of adult life as a normative sequence of life events and of housing careers along an upward and ordered trajectory of increasing opportunity, comfort and wealth. Recent rethinking of residential mobility (Clark, Deurloo and Dieleman 20o6; Coulter, Van Ham and Findlay 2016; Findlay et al. 2015; Geist and McManus 2008; Sanders and Bell 2014) and housing transitions (Beer and Faulkner 2011) has embraced a more differentiated lifecourse narrative (Elder, Johnson and Crosnoe 2003), which emphasises variability in the timing and sequencing of life events, and the diversity of individuals' life outcomes.

Although population research has paid less attention to residential relocations at older ages compared to the peak mobility years in young adulthood, the seminal paper by Litwak and Longino (1987) first recognised the nexus between life events and the migration patterns of retired persons, identifying three types of moves which, they proposed, occur at successive 'stages' in life: retirement migration, kinship or health-related migration and, lastly, moves to institutions. Their model of later-life migration inspired much of the subsequent research on retirement and health-related migration, and empirical evidence from several countries tends to support their conceptualisation of residential mobility in later life as reflecting the needs and motivations of these life phases. For Britain, existing studies have reported that residential moves 


\section{Francesca Fiori et al.}

are often associated with changes in economic activity status, in particular with individuals and/or their spouses retiring from paid employment (Banks et al. 2012; Ermisch and Jenkins 1999; Evandrou, Falkingham and Green 2010; Uren and Goldring 2007). The relationship between increasing disability levels and residential mobility at older ages has also been widely documented for the UK (Al-Hamad, Flowerdew and Hayes 1997; Evandrou, Falkingham and Green 2010; Ford 1993; Uren and Goldring 2007). Glaser and Grundy (1998), for example, in a study focusing on individuals aged $6_{5}$ and over, observed that poor health is positively associated with a greater likelihood of changes in both living arrangements and residential address, in accordance with the hypothesis of support-related migration at older ages.

Although empirical evidence supports the idea that moves at older ages are often associated with lifestyle changes around the time of retirement and then with failing health later in life, past research has also noted the limitations of this model in relation to contemporary residential mobility. As life expectancy has increased, so the time-span available to make residential moves at older ages has expanded. Further, social and attitudinal changes often associated with the Second Demographic Transition have altered the range of motivations for moving house, as well as the timing and sequencing of moves. For instance, residential relocation and housing decision-making at older ages have become increasingly affected by rising rates of marital instability and by consequent trends in either re-partnering or solo-living (Ermisch and Jenkins 1999; Evandrou, Falkingham and Green 2010). Older individuals are also exposed to new vulnerabilities associated with an ageing body and with a longer period of life spent without a spouse, both of which carry important implications for relocation and housing choices (Glaser and Grundy 1998; Uren and Goldring 2007). Moreover, the prolonged presence of adult children in their parental homes (and their - sometimes serial-returns) poses new challenges for intergenerational relationships in the consumption and re-distribution of housing wealth, both at the household and the societal level (Banks et al. 2012; Coulter, Van Ham and Findlay 2016; Uren and Goldring 2007). Unsurprisingly therefore, Evandrou, Falkingham and Green (2010), drawing upon their findings on the factors associated with residential mobility among people aged $5^{\mathrm{O}}$ and over in Britain in the period 1991-2007, concluded that Litwak and Longino's model needs to be expanded to capture moves associated with changes in household composition. The presence of adult children in the parental household, for example, could be expected to result in increasing residential immobility for some, while divorce and separation leading to increases in solo-living may be having the opposite effect by encouraging residential moves to smaller housing units. 
The lifecourse paradigm (Elder, Johnson and Crosnoe 2003) recognises the importance of individual choice and allows for individual trajectories that are increasingly diverse, fragmented and fluid. Moreover, it emphasises the contextual dimensions of people's lives, suggesting that individual biographies are shaped by a person's relationships with other people in their household, family and social network, as well as by broader macro-processes. Understanding housing transitions as embedded in the lifecourse thus has several advantages. First, it implies no uni-directional or linear family trajectory and housing career. Second, it accepts that the capacity of individuals to express choice in the housing market varies over time and in ways that reflect a broader life path. Lastly, it recognises the complexity of relocations and housing decisions which are influenced by personal and household characteristics.

Not all individuals, when faced with changes in their household circumstances, would be equally likely to move and to adjust their housing consumption. Housing tenure, for instance, constitutes a major source of diversity in the UK, not only as an indicator of social status and personal wealth, but also due to the different opportunities and abilities to reduce housing dissatisfaction for owners and for renters. Thus, householders might simply consider residential adaptation (Morris and Winter 1975) to make their current housing fit their needs. The scope for residential adaptation, however, tends to vary by housing tenure, with home-owners having greater freedom than renters to make modifications to their home.

More often, adjustment in housing consumption involves moving to different housing, although motivations - and thus the type of adjustment sought-are likely to vary. Some older households move to change housing tenure, mostly shifting from ownership to renting (Angelini and Laferrère 2012; Bonnet, Gobillon and Laferrère 2010; Ermisch and Jenkins 1999; Tatsiramos 2006). Such a move allows housing equity to be released for other consumption needs or for intergenerational wealth transfers and is seen as a way of coping with the monetary and non-monetary costs of maintaining a house at older ages. Other types of move involve a change of location in order to make adjustments to house value or rental payments (Ermisch and Jenkins 1999), or to improve quality of life by moving to somewhere with a more pleasant climate or closer to amenities and services, or to be more connected with kinship and friendship networks (Banks et al. 2012; Bonnet, Gobillon and Laferrère 2010). A further type of move is undertaken with the purpose of changing the size of the housing unit, to respond to new household needs resulting from a change in the composition and/or characteristics of the household (Angelini and Laferrère 2012; Bonnet, Gobillon and Laferrère 2010; Ermisch and Jenkins 1999; Luborsky, Lysack and Van Nuil 2011; Tatsiramos 2006). 
Relocation opportunities, however, are not the same for all tenure groups. Whereas personal preferences as well as resources might play an important role in triggering housing adjustments among home-owners and private renters, the options available to households within the social rented sector will be largely constrained by the allocation system which regulates the sector. Under Scottish law, priority would thus be given to larger families in overcrowded housing or families living in unsatisfactory housing conditions (Scottish Government 2001). Older adults requiring supported housing due to disability or frailty are also likely to be given priority allocation within the social renting sector.

This study concentrates its attention on residential moves that result in a change in house size. Our interest lies in the adjustment of housing size per se (i.e. whether older individuals move to smaller or larger housing when they go through important changes in their household conditions) as this relates to the policy issue of whether or not older movers in the owner-occupied sector are releasing 'family housing' by downsizing. The common assumption is that, at older ages, most individuals will tend to reduce housing consumption by downsizing to smaller housing units, often in response to changes in the household such as the loss of a spouse (through death or divorce), the departure of children, retirement from the labour force of one or both spouses, or the increasing risk of deteriorating health. These changes all reconfigure housing needs in terms of space and affect resources available to maintain current housing. A move to a house with fewer rooms may therefore be seen as the best option, both for owner-occupiers and for renters. Nevertheless, some of these lifecourse transitions might conversely favour an increase in housing consumption, especially for home-owners. For instance, a wealth effect arising from the payment of a lump sum following retirement or bereavement might induce households to purchase a larger home, either to improve their quality of life or as an investment which can then be released later in life.

Our empirical analysis of adjustments in housing size is carried out in two stages. First, we observe whether individuals change their address between two consecutive censuses and examine the factors associated with a residential move. Secondly, and only for individuals who change address, we observe whether the move implies any adjustment in housing size and examine the factors associated with upsizing and downsizing for two tenure groups. According to Scotland's Census 2001, over 70 per cent of $55^{-69}$-year-olds in private households were owner-occupiers, and nearly 25 per cent were social renters. The balance consisted of individuals renting from private landlords or living rent-free (National Records of Scotland 2015). Thus, for older adults in Scotland, social renting represents 
the main alternative to owner-occupation. Given the different sets of opportunities and constraints discussed above, our investigation of adjustments in housing consumption is therefore carried out separately for owner-occupiers and social renters. More specifically, and drawing on the literature reviewed above, we address the following research questions:

- Research question 1: Do household changes play a significant role in triggering the residential moves of older individuals and their households in Scotland?

- Research question 2: Do older movers who are (a) owner-occupiers and (b) social renters (and their households) adjust their housing consumption by upsizing or downsizing their accommodation as a response to particular household changes?

\section{Research design}

The empirical analyses use anonymised data from the Scottish Longitudinal Study (SLS) for the period 2001-2011. The SLS is a large-scale linkage study on a 5.3 per cent sample of the Scottish population (approximately 270,000 individuals) based on 20 birthdates. For SLS members in the sample, data from the 1991, 2001 and 2011 censuses are linked together, providing a range of information on their cultural, demographic, economic, health and housing characteristics. A particular strength of the SLS is the linkage to administrative records documenting vital events during each decade. Information on individuals living in the same household at the time of the census is also collected, but these individuals are not followed to subsequent censuses or linked to other data sources (Boyle et al. 2oog). For the purpose of this study, the analytical sample consists of SLS members only but we also make use of information on other individuals in the household to derive measures of household circumstances and their changes over time.

Since the SLS includes statutory data and data collected as a standard administrative function, attrition rates are extremely low and linkage rates for events tend to be very high. It is, however, a sample with replacement - as people leave the sample over time by death and emigration out of Scotland others enter by birth and immigration into the country. Longitudinal analysis of decadal changes is only possible for individuals who are enumerated both at the beginning and end of the interval, so that the behaviour of those who died or emigrated within the decade is not observable.

The SLS comprises a representative sample of the Scottish population and therefore includes all age groups. In this study, we focus on individuals 
aged $55^{-69}$ in 2001 . Around 15 per cent of this group died over the decade and less than 2 per cent migrated out of Scotland. For our analyses, we select a sub-sample of 27,092 individuals aged $55^{-69}$ who were living in private households in 2001, and who were still living in private households ten years later. ${ }^{1}$ Those living in institutional settings either at the start or end of the decade $(0.4 \%$ in 2001 and $1.4 \%$ in 2011) are thus excluded from our analyses.

For our selected sample, we model housing consumption adjustments during the decade in a sequential process that examines:

1. The probability of having made a residential move by the end of the decade.

2. The probability of housing consumption adjustments, conditional on having made a residential move, for those who are (a) owner-occupiers and (b) social renters in 2001.

An alternative to this sequential approach would have been to model residential mobility and the associated housing consumption adjustments simultaneously, which could yield more efficient parameter estimates. However, there is no evidence in the literature as to which variables would identify the housing adjustments equation (i.e. which variables in the mobility equations would be excluded from the adjustment equations) ( see Bonnet, Gobillon and Laferrère 2010; Ermisch and Jenkins 1999; Rabe and Taylor 2009). Thus, the lack of a plausible and powerful instrumental variable led us to choose the sequential approach as the most convincing strategy.

Logistic regression models are used to estimate the SLS members' probability of having made a residential move by 2001. A residential move is defined as a change of address between two consecutive censuses, based on the comparison of the unit postcode ${ }^{2}$ of residence at each census.

Formally, the model can be expressed as follows (Agresti 2013):

$$
\pi_{i}=\frac{\exp \left(\alpha+\beta X_{i}\right)}{1+\exp \left(\alpha+\beta X_{i}\right)}
$$

where $\pi_{i}$ is the probability of a residential move by the end of the decade for the individual $i$ and $X_{i}$ is the vector of individual-level covariates.

Then, and only for individuals who are owner-occupiers or social renters and did change address between 2001 and 2011 , we observe whether the move implied any adjustment in their housing size. Housing adjustments are defined as moves to larger (upsizing) or smaller (downsizing) accommodation, measured by change in the number of rooms 3 in the housing unit occupied by the individual and their household in 2011 compared with 
2001. We use multinomial logistic regression models - an extension of the ordinary logistic regression for multiple outcomes - to compare the probability of an individual downsizing and that of upsizing to the base category of individuals moving to housing of the same size. Models are estimated separately by housing tenure at time I (owner-occupiers; social renters).

Formally, the probability of housing adjustments conditional on a residential move can be expressed as follows (Agresti 2013):

$$
\pi_{i}^{(m)}=\frac{\exp \left(\alpha^{(m)}+\beta^{(m)} X_{i}\right)}{1+\exp \left(\alpha^{(2)}+\beta^{(2)} X_{i}\right)+\exp \left(\alpha^{(3)}+\beta^{(3)} X_{i}\right)}
$$

where $\pi_{i}^{(m)}$ is the probability of being in the alternative $m$ of the categorical response $Y_{i}$ (with $m=1$ if the individual moved to same-size housing - the base category, $m=2$ if the individual moved to smaller housing and $m=3$ if the individuals moved to larger housing). Again, $X_{i}$ is the vector of individual-level covariates.

The choice of explanatory variables stems from the literature reviewed earlier, and includes the main socio-demographic characteristics and lifecourse factors that have been associated with mobility and housing consumption at older age. The core variables of our analyses summarise the household's initial circumstances and the changes occurring between time 1 (2001) and time 2 (2011). A first variable, changes in health status compares information on whether an individual and their spouse/partner (when present) reported any limiting long-term illness at the beginning and end of the decade (no limiting long-term illness at time 1 or at time 2; at least one spouse/partner with limiting long-term illness already at time 1; at least one spouse/partner developed a limiting long-term illness between time 1 and time 2 ). Similarly, changes in household activity status measures the household's transition to economic inactivity over the decade (i.e. the transition of the SLS member and of their spouse/partner - when present); thus, for example, a household is defined as active if either the SLS member or their spouse/partner is still in the labour force at time 2. Three categories are distinguished (household already inactive at time 1 ; household retired between time 1 and time 2; household still active at time 2). Information on household composition at each census is used to estimate two other major lifecourse events, union dissolution and (re-)partnering. The variable union transitions 4 distinguishes five categories (with the same spouse/partner at time 1 and at time 2; with a spouse/partner at time 1 but not at time 2; with a different spouse/partner at time 1 and at time 2; with no spouse/partner at time 1, but a spouse/partner at time 2; no 


\section{Francesca Fiori et al.}

spouse/partner at time 1 or at time 2). The final core variable, children leaving home, accounts for the presence and/or departure of children from their parental home over the decade (children (still) in the household at time 2; all children have left the household by time 2; no children in the household at time 1 or at time 2 ).

Importantly, the models also include a set of variables which control for initial conditions by measuring demographic and socio-economic characteristics of individuals at time 1: gender, age $\left(55^{-59}, 60-64\right.$ and $\left.65^{-69}\right)$, educational level (below post-secondary; post-secondary) and social class $^{5}$ (professional/managerial; skilled non-manual/manual; partly skilled/ unskilled; never worked). Educational level and social class also serve as a proxy measure for income and wealth, as this information is not available in the SLS. A further control variable, number of rooms, accounts for housing size at time 1 and is an indicator both of wealth and of opportunities for upsizing/downsizing.

In the model on residential mobility only, we further account for initial conditions by adding a combination of tenure and type of accommodation (owned house; owned flat; social rented house; social rented flat; private rented accommodation), and a geographical variable, place of residence, ${ }^{6}$ based on settlement size, which controls for variations in housing stock (large urban area; other urban area; small town and village; rural area). We do not include these variables in the housing adjustment models for reasons of collinearity but instead provide descriptive statistics on the associations between upsizing and downsizing and changes in tenure, type of housing and place of residence.

Tables 1 and 2 present the percentage distribution of all covariates included in the models. Table 1 refers to all SLS members aged $55^{-69}$ in 2001 , distinguished by whether or not they had changed address by 2011. Table 2 is limited to SLS members who were living at a different address in 2011 , distinguished by type of housing adjustment and presented separately for owner-occupiers and for social renters.

Our data show that the large majority of older adults do not move house during the decade: only 19.4 per cent of $55^{-69}$-year-olds in 2001 are living at a different address a decade later. Among owner-occupiers who do change residential address, more than half (52.6 per cent) move to smaller-sized housing, less than a quarter (21.6 per cent) move to a housing unit with the same number of rooms, and the remaining quarter (25.8 per cent) move to larger housing. Compared to owner-occupiers, a larger proportion of social renters moves to same-sized housing (30.1 per cent), whereas a lower proportion moves to smaller-sized housing (42.4 per cent). Just over a quarter (27.6 per cent) move to housing with more rooms, and, of those, around a third also change tenure. 
T A B LE 1. Percentage distribution of the covariates included in the analyses: Scottish Longitudinal Study (SLS) members aged 55-69 in 200 I

\begin{tabular}{|c|c|c|c|}
\hline & $\begin{array}{l}\text { SLS member } \\
\text { did not move } \\
\text { between } \\
\text { t1 and } t 2\end{array}$ & $\begin{array}{l}\text { SLS member } \\
\text { moved } \\
\text { between t1 } \\
\text { and t } 2\end{array}$ & Total \\
\hline \multicolumn{4}{|l|}{ Gender: } \\
\hline Male & $45 \cdot 6$ & $4^{6.6}$ & 45.8 \\
\hline Female & $54 \cdot 4$ & $53 \cdot 4$ & $54 \cdot 2$ \\
\hline \multicolumn{4}{|l|}{ Age-class at t 1 : } \\
\hline $55^{-59}$ & 38.6 & $44 \cdot 2$ & $39 \cdot 7$ \\
\hline $6 o-64$ & $33 \cdot 4$ & 32.9 & $33 \cdot 3$ \\
\hline $65^{-69}$ & 28.0 & 22.9 & $27 \cdot 1$ \\
\hline \multicolumn{4}{|l|}{ Educational qualification: } \\
\hline No post-secondary education & $79 \cdot 7$ & 80.1 & 79.8 \\
\hline Post-secondary education & 20.3 & $19 \cdot 9$ & 20.2 \\
\hline \multicolumn{4}{|l|}{ Social class at $\mathrm{t} 1$ : } \\
\hline In employment - professional/managerial & 28.7 & $29 \cdot 7$ & 28.9 \\
\hline In employment - skilled & 38.4 & 36.6 & 38.1 \\
\hline In employment - partly/un-skilled & $23 \cdot 4$ & 23.1 & $23 \cdot 3$ \\
\hline Never worked in the last 10 years & $9 \cdot 5$ & 10.7 & $9 \cdot 7$ \\
\hline \multicolumn{4}{|l|}{ Tenure and type of accommodation: } \\
\hline Home-owner - house & 67.6 & $53 \cdot 3$ & 64.8 \\
\hline Home-owner - flat & 10.2 & 14.2 & 11.0 \\
\hline Social renting - house & 11.9 & 8.7 & 11.3 \\
\hline Social renting - flat & $7 \cdot 5$ & 13.9 & 8.8 \\
\hline Private renting/other & 2.0 & 7.8 & 3.1 \\
\hline Missing & 0.8 & 2.1 & 1.1 \\
\hline Mean number of rooms at $\mathrm{t} 1$ & $5 \cdot 1$ & $5 \cdot 1$ & $5 \cdot 1$ \\
\hline \multicolumn{4}{|l|}{ Changes in health status between $\mathrm{t} 1$ and $\mathrm{t} 2$ : } \\
\hline None in the hhd with LLTI at $\mathrm{t} 1$ or at $\mathrm{t} 2$ & 36.5 & 33.1 & 35.8 \\
\hline At least 1 in the hhd developed LLTI between t 1 and t2 & 20.9 & 20.8 & 20.8 \\
\hline At least 1 in the hhd with LLTI at $t 1$ & 42.7 & $4^{6.1}$ & $43 \cdot 3$ \\
\hline \multicolumn{4}{|l|}{ Changes in household activity status between $\mathrm{t} 1$ and $\mathrm{t} 2$ : } \\
\hline Hhd inactive at $\mathrm{t} 1$ and $\mathrm{t} 2$ & $49 \cdot 6$ & $47 \cdot 9$ & $49 \cdot 3$ \\
\hline Hhd retired between $\mathrm{t} 1$ and $\mathrm{t} 2$ & 34.8 & 38.2 & $35 \cdot 4$ \\
\hline Hhd still active at $\mathrm{t} 2$ & $15 \cdot 6$ & $13 \cdot 9$ & $15 \cdot 3$ \\
\hline \multicolumn{4}{|l|}{ Union transitions between $\mathrm{t} 1$ and $\mathrm{t} 2$ : } \\
\hline With same spouse/partner at t 1 and t2 & 63.8 & $53 \cdot 4$ & 61.8 \\
\hline With spouse/partner at $\mathrm{t}_{1}$ but no spouse/partner at $\mathrm{t} 2$ & 11.6 & $15 \cdot 5$ & 12.3 \\
\hline With different spouse/partner at t2 & $3 \cdot 5$ & 3.8 & 3.6 \\
\hline With no spouse/partner at t1 but spouse/partner at t2 & 0.8 & $3 \cdot 4$ & 1.3 \\
\hline With no spouse/partner at t 1 or at $\mathrm{t} 2$ & 20.4 & $23 \cdot 9$ & 21.0 \\
\hline \multicolumn{4}{|l|}{ Children leaving between $\mathrm{t} 1$ and $\mathrm{t} 2$ : } \\
\hline No children at $t 1$ or at $t 2$ & 76.1 & 77.8 & 76.4 \\
\hline All children left between $\mathrm{t} 1$ and $\mathrm{t} 2$ & 12.4 & $13 \cdot 7$ & 12.7 \\
\hline Child/ren living with parents at t2 & 11.5 & 8.5 & 10.9 \\
\hline
\end{tabular}


T A B LE 1. (Cont.)

\begin{tabular}{|c|c|c|c|}
\hline & $\begin{array}{l}\text { SLS member } \\
\text { did not move } \\
\text { between } \\
\text { t1 and } t 2\end{array}$ & $\begin{array}{l}\text { SLS member } \\
\text { moved } \\
\text { between } \mathrm{t} 1 \\
\text { and t } 2\end{array}$ & Total \\
\hline \multicolumn{4}{|l|}{ Place of residence at $t 1$ : } \\
\hline Large urban area & $33 \cdot 5$ & 37.2 & 34.2 \\
\hline Other urban area & 30.2 & $27 \cdot 9$ & 29.8 \\
\hline Small town/village & 14.8 & 11.8 & 14.2 \\
\hline Rural area & 21.4 & 23.1 & 21.8 \\
\hline Total & 100.0 & 100.0 & 100.0 \\
\hline \multicolumn{4}{|l|}{ Sample size: } \\
\hline $\mathrm{N}$ & $21,83^{6}$ & $5,25^{6}$ & 27,092 \\
\hline$\%$ & 80.6 & $19 \cdot 4$ & 100.0 \\
\hline
\end{tabular}

Notes: t1: time 1 (2001). t2: time 2 (2011). hhd: household. LLTI: limiting long-term illness. Source. Authors' analysis of the Scottish Longitudinal Study.

The adjustment of actual to desired housing size often involves other changes. Older movers may choose a different housing tenure or a different type of accommodation and/or location. Table 3 explores these relationships in more detail for the two main tenure groups, home-owners and social renters.

Among both home-owners and social renters, most residential moves (nearly $80 \%$ ) occur within the same housing sector. Nevertheless, a significant minority of home-owners $(15 \%)$ move to the social rented sector, mostly downsizing to smaller housing. Conversely, a non-negligible proportion of social renters $(13 \%)$ moves to owner-occupied housing, and nearly half of these moves are directed to larger housing.

The majority of older home-owners in the SLS sample live in houses rather than flats, and most of their moves are to the same house type. A quarter of home-owners who move, however, do so from a house to a flat, and this is mostly to smaller-sized accommodation. Further, of the minority of homeowners who were living in a flat at the start of the decade, a substantial proportion upsize to larger housing by moving to a house. In contrast, two-thirds of movers from the social rented sector were living in a flat at the start of the decade, and the majority still live in a flat after a move. Also among social renters, less common moves from a house to flat, and from a flat to a house, are associated with higher proportions of movers adjusting their housing size.

Lastly, for both home-owners and social renters a move may imply a change in their place of residence, although most moves across both tenures occur within the same urban/rural category. Interestingly, among home-owners who move, the proportion of individuals undertaking upward and downward housing adjustments does not vary depending on the urban/rural origin and 
T A B L E 2. Percentage distribution of the covariates included in the analyses: Scottish Longitudinal Study members aged 55-60 in 200 I who are living at a different address in 201 I, by housing tenure at time I

Same

Downsized size Upsized Total

Housing tenure at tI: owner-occupation:

Gender:

Male

Female

Age-class at t1:

$$
\begin{aligned}
& 55^{-59} \\
& 60-64 \\
& 65-69
\end{aligned}
$$

Educational qualification:

No post-secondary education

Post-secondary education

Social class at $\mathrm{t} 1$ :

In employment - professional/managerial

In employment - skilled

In employment - partly/un-skilled

Never worked in the last 10 years

Mean number of rooms at $\mathrm{t} 1$ :

Changes in health status between $\mathrm{t}_{1}$ and $\mathrm{t} 2$ :

None in the hhd with LLTI at $\mathrm{t} 1$ or at $\mathrm{t} 2$

At least 1 in the hhd developed LLTI between $t_{1}$ and $t 2$

At least 1 in the hhd with LLTI at $\mathrm{t} 1$

Changes in household activity status between t1 and t2:

Hhd inactive at $\mathrm{t} 1$ and $\mathrm{t} 2$

Hhd retired between $\mathrm{t} 1$ and $\mathrm{t} 2$

Hhd still active at t2

Union transitions between $\mathrm{t} 1$ and $\mathrm{t} 2$ :

With same spouse/partner at $\mathrm{t} 1$ and $\mathrm{t} 2$

With spouse/partner at t1 but no spouse/partner at t2

With different spouse/partner at t2

With no spouse/partner at t1 but spouse/partner at t2

With no spouse/partner at t1 or at 2

Children leaving between $\mathrm{t} 1$ and $\mathrm{t} 2$ :

No children at $\mathrm{t} 1$ or at $\mathrm{t} 2$

All children left between $\mathrm{t} 1$ and $\mathrm{t} 2$

Child/ren living with parents at t2

Total

Sample size:

$\mathrm{N}$
$\%$

Housing tenure at $t_{I}$ : social renting:

Gender:

\begin{tabular}{|c|c|c|c|}
\hline $4^{6.3}$ & $4^{6.3}$ & 49.0 & 47.0 \\
\hline $53 \cdot 7$ & $53 \cdot 7$ & $5^{1.0}$ & 53.0 \\
\hline 42.5 & 43.8 & 47.2 & 44.0 \\
\hline 31.8 & 31.8 & 32.6 & 32.0 \\
\hline $25 \cdot 7$ & 24.4 & 20.2 & 24.0 \\
\hline $74 \cdot 9$ & 80.6 & 71.6 & $75 \cdot 3$ \\
\hline 25.1 & $19 \cdot 4$ & 28.4 & $24 \cdot 7$ \\
\hline $35 \cdot 9$ & 28.8 & $4^{0.1}$ & 35.5 \\
\hline $37 \cdot 5$ & 43.2 & 34.5 & $3^{8.0}$ \\
\hline 19.6 & 19.6 & 18.3 & 19.3 \\
\hline 6.9 & 8.5 & $7 \cdot 1$ & $7 \cdot 3$ \\
\hline 6.3 & $4 \cdot 9$ & 4.6 & 5.6 \\
\hline $37 \cdot 5$ & 35.9 & $4^{2.0}$ & $3^{8.3}$ \\
\hline 20.4 & 20.5 & 21.0 & 20.6 \\
\hline $4^{2.1}$ & $43 \cdot 7$ & 37.0 & $4^{1.1}$ \\
\hline 42.8 & 42.2 & $4^{1.4}$ & $4^{2 \cdot 3}$ \\
\hline $4^{2} \cdot 5$ & $4^{1.5}$ & $4^{0.6}$ & 41.8 \\
\hline 14.7 & 16.3 & 18.0 & 15.9 \\
\hline
\end{tabular}

Male

Female $\begin{array}{llll}58.2 & 62.5 & 65.8 & 61.1\end{array}$

$20.7 \quad 13.7 \quad 8.6 \quad 16.1$

$\begin{array}{llll}3.4 & 3.1 & 5.9 & 4.0\end{array}$

$\begin{array}{llll}1.1 & 2.6 & 6.3 & 2.8\end{array}$

$16.6 \quad 18.1 \quad 13.4 \quad 16.1$

$\begin{array}{rrrr}76.8 & 80.6 & 76.2 & 77.5 \\ 17.3 & 11.7 & 13.0 & 15.0 \\ 5.9 & 7.7 & 10.8 & 7.6 \\ 100.0 & 100.0 & 100.0 & 100.0 \\ & & & \\ 1,865 & 767 & 917 & 3,549 \\ 52.6 & 21.6 & 25.8 & 100.0\end{array}$

$42.1 \quad 43.0 \quad 45 \cdot 4 \quad 43 \cdot 3$

$57.9 \quad 57.0 \quad 54.6 \quad 56.7$ 
T A B LE 2. (Cont.)

\begin{tabular}{|c|c|c|c|c|}
\hline & Downsized & $\begin{array}{l}\text { Same } \\
\text { size }\end{array}$ & Upsized & Total \\
\hline \multicolumn{5}{|l|}{ Age-class at $\mathrm{t} 1$ : } \\
\hline $55^{-59}$ & $43 \cdot 3$ & 42.5 & 44.5 & $43 \cdot 4$ \\
\hline $6 o-64$ & $35 \cdot 7$ & 33.8 & 32.6 & $34 \cdot 3$ \\
\hline $65^{-69}$ & 21.0 & $23 \cdot 7$ & 22.9 & 22.4 \\
\hline \multicolumn{5}{|l|}{ Educational qualification: } \\
\hline No post-secondary education & 97.0 & $95 \cdot 5$ & 93.0 & $95 \cdot 5$ \\
\hline Post-secondary education & $3 \cdot 0$ & $4 \cdot 5$ & 7.0 & $4 \cdot 5$ \\
\hline \multicolumn{5}{|l|}{ Social class at t1: } \\
\hline In employment - professional/managerial & 8.9 & 11.2 & 12.2 & 10.5 \\
\hline In employment - skilled & $37 \cdot 3$ & 37.2 & 32.3 & $35 \cdot 9$ \\
\hline In employment - partly/un-skilled & $34 \cdot 7$ & $37 \cdot 7$ & 28.4 & 33.9 \\
\hline Never worked in the last 10 years & 19.0 & 14.0 & 27.1 & 19.7 \\
\hline Mean number of rooms at $\mathrm{t} 1$ : & 4.5 & $3 \cdot 5$ & 2.8 & 3.7 \\
\hline \multicolumn{5}{|l|}{ Changes in health status between $\mathrm{t} 1$ and $\mathrm{t} 2$ : } \\
\hline None in the hhd with LLTI at $\mathrm{t} 1$ or at $\mathrm{t} 2$ & 16.3 & 19.0 & 18.3 & 17.6 \\
\hline At least 1 in the hhd developed LLTI between $\mathrm{t} 1$ and $\mathrm{t} 2$ & 21.4 & $15 \cdot 4$ & 19.8 & 19.2 \\
\hline At least 1 in the hhd with LLTI at $\mathrm{t} 1$ & 62.3 & 65.6 & 61.9 & 63.2 \\
\hline \multicolumn{5}{|l|}{ Changes in household activity status between $\mathrm{t} 1$ and $\mathrm{t} 2$ : } \\
\hline Hhd inactive at $\mathrm{t} 1$ and $\mathrm{t} 2$ & $63 \cdot 3$ & 67.9 & 73.2 & $67 \cdot 4$ \\
\hline Hhd retired between $\mathrm{t} 1$ and $\mathrm{t} 2$ & 31.2 & $25 \cdot 4$ & 21.3 & 26.7 \\
\hline Hhd still active at $\mathrm{t} 2$ & 5.6 & 6.7 & $5 \cdot 5$ & $5 \cdot 9$ \\
\hline \multicolumn{5}{|l|}{ Union transitions between $\mathrm{t} 1$ and t2: } \\
\hline With same spouse/partner at t1 and t2 & 32.7 & 35.8 & 31.4 & $33 \cdot 3$ \\
\hline With spouse/partner at $\mathrm{t} 1$ but no spouse/partner at $\mathrm{t} 2$ & $19 \cdot 4$ & 12.8 & 10.7 & 15.0 \\
\hline With different spouse/partner at t2 & 2.8 & 2.2 & $4 \cdot 3$ & 3.0 \\
\hline With no spouse/partner at t1 but spouse/partner at t2 & 2.4 & $3 \cdot 9$ & $7 \cdot 9$ & $4 \cdot 4$ \\
\hline With no spouse/partner at t 1 or at $\mathrm{t} 2$ & $4^{2.7}$ & $45 \cdot 3$ & $45 \cdot 7$ & $44 \cdot 3$ \\
\hline \multicolumn{5}{|l|}{ Children leaving between $\mathrm{t} 1$ and $\mathrm{t} 2$ : } \\
\hline No children at $\mathrm{t} 1$ or at $\mathrm{t} 2$ & 78.6 & 78.5 & 78.4 & 78.5 \\
\hline All children left between $\mathrm{t} 1$ and $\mathrm{t} 2$ & $15 \cdot 3$ & 10.1 & 5.2 & 10.9 \\
\hline Child/ren living with parents at t2 & 6.2 & 11.5 & 16.5 & 10.6 \\
\hline Total & 100.0 & 100.0 & 100.0 & 100.0 \\
\hline \multicolumn{5}{|l|}{ Sample size: } \\
\hline $\mathrm{N}$ & $5^{\circ} 4$ & $35^{8}$ & 328 & 1,190 \\
\hline$\%$ & $4^{2} \cdot 4$ & 30.1 & 27.6 & 100.0 \\
\hline
\end{tabular}

Notes: t1: time 1 (2001). t2: time 2 (2011). hhd: household. LLTI: limiting long-term illness. Source: Authors' analysis of the Scottish Longitudinal Study.

destination of the move - with one significant exception: moves from urban areas to small towns or rural areas appear to be more associated with the upsizing of housing compared to other types of geographical moves. Although similar proportions of upsizers are found among social renters who move into - or indeed away from - small towns or rural areas, the number of such moves is small. The majority of social renters move within 
TABLE 3. Housing adjustments and changes of tenure, type of housing and place of residence: Scottish Longitudinal Study members aged 55-69 in $20 O I$ who are living at a different address in $201 \mathrm{I}$, by housing tenure at time $I$

Total

Downsized $\begin{gathered}\text { Same } \\ \text { size }\end{gathered} \stackrel{\text { Upsized }}{$\cline { 3 - 3 }$}$

Housing tenure at tI: owner-occupation:

Percentages

Tenure at t2:

Ownership

Social rent

Other tenure

$4^{8.8}$

70.9

$53 \cdot 4$

Changes of housing type between $\mathrm{t} 1$ and $\mathrm{t} 2$ :

From house to house

From house to flat

From flat to flat

From flat to house

Changes of place of residence between $\mathrm{t} 1$ and $\mathrm{t} 2$ :

Within/between large urban areas

Within/between other urban areas

Within/between small towns/ rural areas

From large/other urban areas to small towns/ rural areas

From small towns/rural areas to large/other

Total urban areas

Housing tenure at tI: social renting:

Tenure at t2:

Ownership

Social rent

Other tenure

Changes of housing type between $\mathrm{t} 1$ and $\mathrm{t} 2$ :

From house to house

From house to flat

From flat to flat

From flat to house

Changes of place of residence between $\mathrm{t} 1$ and t2:

Within/between large urban areas

Within/between other urban areas

Within/between small towns/rural areas

From large/other urban areas to small towns/ rural areas

From small towns/rural areas to large/other Total

\begin{tabular}{|c|c|c|c|c|}
\hline $4^{8.1}$ & 21.7 & 30.2 & 100.0 & 1,972 \\
\hline 77.8 & 16.8 & $5 \cdot 4$ & 100.0 & 832 \\
\hline $47 \cdot 7$ & $29 \cdot 4$ & 22.9 & 100.0 & 371 \\
\hline 24.6 & 24.1 & $5^{1 \cdot 3}$ & 100.0 & 374 \\
\hline $5^{2.7}$ & 23.0 & $24 \cdot 4$ & 100.0 & 1,010 \\
\hline 57.1 & 20.3 & 22.7 & 100.0 & 829 \\
\hline $5^{2.7}$ & 21.8 & 25.6 & 100.0 & 919 \\
\hline $43 \cdot 3$ & 19.2 & 37.5 & 100.0 & 443 \\
\hline $5^{2.9}$ & 23.6 & 23.6 & 100.0 & $34^{8}$ \\
\hline 2.6 & 21.6 & 25.8 & 100.0 & 3,549 \\
\hline 28.9 & 25.0 & $4^{6.1}$ & 100.0 & $15^{2}$ \\
\hline $4^{6.3}$ & 31.4 & 22.4 & 100.0 & 947 \\
\hline 24.2 & $25 \cdot 3$ & $5^{0.5}$ & 100.0 & $9^{1}$ \\
\hline 49.6 & 21.7 & 28.7 & 100.0 & $25^{8}$ \\
\hline 60.8 & 22.6 & 16.6 & 100.0 & 199 \\
\hline $3^{6.3}$ & $3^{6.5}$ & $27 \cdot 3$ & 100.0 & 488 \\
\hline 31.8 & $3^{2.2}$ & $35 \cdot 9$ & 100.0 & 245 \\
\hline $37 \cdot 3$ & 33.6 & 29.1 & 100.0 & $55^{\circ}$ \\
\hline & 26.6 & 22.6 & 100.0 & 305 \\
\hline $4^{8}$ & 27.6 & $24 \cdot 3$ & 100.0 & 210 \\
\hline $3^{2.8}$ & $29 \cdot 7$ & 37.5 & 100.0 & 64 \\
\hline $3^{6.1}$ & 24.6 & $39 \cdot 3$ & 100.0 & 61 \\
\hline & 30. & 27.6 & 100.0 & 1,190 \\
\hline
\end{tabular}

Notes: t1: time 1 (2001). t2: time 2 (2011).

Source. Authors' analysis of the Scottish Longitudinal Study. 
or between urban areas, as is expected given the geographical concentration of Scotland's social housing stock in larger settlements.

\section{Results}

\section{Household changes and residential moves}

Our first research question addresses the role of changes in personal and household circumstances in prompting residential moves. Results are derived from the estimation of a logistic regression model and are reported as odds ratios, adjusted for the effects of all control variables described in the previous section (Table 4 ).

In line with past studies, our model results support the importance of certain lifecourse events and changes in household circumstances as significant predictors of moving house among older adults in Scotland. First, we find that declining health is a key trigger of a residential move; older adults in Scotland are significantly more likely to move if at least one household member already had a limiting long-term illness in 2001 or if their health deteriorates during the decade. Another lifecourse event which is often associated with the decision to relocate at older ages is retirement from the labour market. Our model indicates that households where both spouses/partners have become economically inactive during the decade are the most likely to move house.

Declining health and retirement are well-established determinants of moves at older ages but a comparison of $z$-scores in the model suggests that there are other triggers for moving house at older ages that may be even more important. Almost 20 per cent of older adults in our sample experienced a change in their partnership status during the decade, either through separation/divorce or, more usually, because of the death of their spouse/partner. A minority of them re-partnered following the dissolution of their union. As expected, all these changes are associated with a greater propensity to move house, whereas older adults who lived with the same partner throughout the period are the least likely to be living at a different address by the end of the decade.

Since the youngest age group in our sample of older adults is $55^{-59}$ at the start of observation, most of their children have already left the parental home. Nevertheless, just below a quarter (23.6 per cent) had children living in the household in 2001. The multivariate analysis shows that the presence of adult children in the household reduces the propensity to move house, whereas their departure during the decade is associated with a higher (albeit not statistically significant) probability of a residential move.

Overall, we find that several household changes act as triggers to a residential move. Not only do our results confirm the importance of 
T A B LE 4. Household changes and the probability of a residential move: logistic regression model

\begin{tabular}{|c|c|c|c|}
\hline & $\begin{array}{c}\text { Adjusted } \\
\text { odds ratio }^{1}\end{array}$ & SE & $z$-score \\
\hline \multicolumn{4}{|l|}{ Changes in health status between $\mathrm{t}_{1}$ and t2: } \\
\hline None in the hhd with LLTI at $\mathrm{t}_{1}$ or at $\mathrm{t} 2$ & 1 & & \\
\hline At least 1 in the hhd developed LLTI between t1 and t2 & $1.14^{* *}$ & 0.05 & 2.98 \\
\hline At least 1 in the hhd with LLTI at t 1 & $1.22 * * *$ & 0.05 & 5.21 \\
\hline \multicolumn{4}{|l|}{ Changes in household activity status between $\mathrm{t} 1$ and $\mathrm{t} 2$ : } \\
\hline Hhd inactive at $\mathrm{t}_{1}$ and $\mathrm{t} 2$ & 1 & & \\
\hline Hhd retired between $\mathrm{t} 1$ and $\mathrm{t} 2$ & $1.15^{* * *}$ & 0.05 & $3 \cdot 5^{\mathrm{O}}$ \\
\hline Hhd still active at t2 & 0.89 & 0.05 & -2.05 \\
\hline \multicolumn{4}{|l|}{ Union transitions between $\mathrm{t}_{1}$ and $\mathrm{t} 2$ : } \\
\hline With same spouse/partner at $\mathrm{t}_{1}$ and $\mathrm{t} 2$ & 1 & & \\
\hline With spouse/partner at t1 but no spouse/partner at t2 & $1.67 * * *$ & 0.08 & 10.62 \\
\hline With different spouse/partner at t2 & $1.27 * *$ & 0.11 & 2.83 \\
\hline With no spouse/partner at t1 but spouse/partner at t2 & $4 \cdot 79^{* * *}$ & 0.55 & 13.66 \\
\hline With no spouse/partner at t 1 or at $\mathrm{t} 2$ & $1.3^{1 * * *}$ & 0.06 & 6.05 \\
\hline \multicolumn{4}{|l|}{ Children leaving between $\mathrm{t}_{1}$ and $\mathrm{t} 2$ : } \\
\hline No children at $\mathrm{t} 1$ or at $\mathrm{t} 2$ & 1 & & \\
\hline All children left between $\mathrm{t} 1$ and $\mathrm{t} 2$ & 1.06 & 0.05 & 1.15 \\
\hline Child/ren living with parents at t2 & $0.70^{* * * *}$ & 0.04 & $-6.4^{1}$ \\
\hline
\end{tabular}

Notes: $\mathrm{N}=27,092 . \mathrm{SE}$ : standard error. t1: time 1 (2001). t2: time 2 (2011). hhd: household. LLTI: limiting long-term illness. 1. Adjusted for: age, gender, educational attainment, social class, number of rooms at $\mathrm{t}$, housing tenure and type of accommodation at t1, place of residence at $t_{1}$ (see Table Al in the Appendix for full model results).

Source: Authors' analysis of the Scottish Longitudinal Study.

Significance levels: $* * p<0.01, * * * p<0.001$.

health-related moves and retirement moves for older adults in Scotland but they also support the argument that Litwak and Longino's (1987) typology needs to be extended to incorporate moves prompted by marital dissolution/death of a spouse/partner and children leaving home.

\section{Household changes and housing adjustments}

In addition to investigating the role of household transitions in triggering residential moves at older ages, our second research question seeks to determine their influence on housing consumption among those who do move. Of particular interest is whether each of the changes that triggers a move is further related to a change in the size of the household's accommodation for owner-occupiers and social renters. We therefore estimate the probability of downsizing or upsizing for older adults who move to a different address between 2001 and 2011 , separately by housing tenure at time 1 (Table 5 ). 


\begin{tabular}{|c|c|c|c|c|c|c|}
\hline & \multicolumn{3}{|c|}{ Downsizing } & \multicolumn{3}{|c|}{ Upsizing } \\
\hline & Relative risk ratio & $\mathrm{SE}$ & $z$-score & Relative risk ratio & SE & $z$-score \\
\hline \multicolumn{7}{|l|}{ Housing tenure at tI: owner-occupation: } \\
\hline \multicolumn{7}{|l|}{ Gender: } \\
\hline Male (Ref.) & 1 & & & 1 & & \\
\hline Female & 0.96 & o.09 & -0.44 & 1.02 & 0.11 & 0.16 \\
\hline \multicolumn{7}{|l|}{ Age-class at t1: } \\
\hline 55-59 (Ref.) & 1 & & & & & \\
\hline $60-64$ & 1.03 & 0.12 & 0.24 & 0.96 & 0.12 & $-0.3^{1}$ \\
\hline $65^{-69}$ & 1.12 & 0.15 & 0.83 & 0.82 & 0.12 & -1.35 \\
\hline \multicolumn{7}{|l|}{ Educational qualification at $\mathrm{t} 1$ : } \\
\hline No post-secondary education (Ref.) & 1 & & & 1 & & \\
\hline Post-secondary education & $0.71^{*}$ & 0.09 & $-2.5^{6}$ & $1.70^{* * * *}$ & 0.24 & $3 \cdot 75$ \\
\hline \multicolumn{7}{|l|}{ Social class at $\mathrm{t} 1$ : } \\
\hline In employment - professional/managerial (Ref.) & 1.02 & 0.13 & 0.14 & $1.61 * * *$ & 0.21 & 3.62 \\
\hline In employment - skilled & 1 & & & 1 & & \\
\hline In employment - partly/un-skilled & $1.57^{* * *}$ & 0.20 & $3 \cdot 59$ & 1.09 & 0.15 & 0.64 \\
\hline Never worked in the last 10 years & 1.05 & 0.19 & 0.26 & 1.01 & 0.21 & 0.05 \\
\hline Number of rooms at t1 & $1.87 * * *$ & 0.07 & 17.04 & 0.74 & 0.03 & -6.96 \\
\hline \multicolumn{7}{|l|}{ Changes in health status between $\mathrm{t}_{1}$ and $\mathrm{t} 2$ : } \\
\hline None in the hhd with LLTI at $\mathrm{t} 1$ or at $\mathrm{t} 2$ & 1 & & & 1 & & \\
\hline At least 1 in the hhd developed LLTI between t 1 and t2 & 1.16 & 0.15 & 1.15 & 0.87 & 0.12 & $-1.3^{6}$ \\
\hline At least 1 in the hhd with LLTI at t1 & $1.22 \dagger$ & 0.13 & 1.81 & $0.73^{* *}$ & 0.08 & -3.62 \\
\hline \multicolumn{7}{|l|}{ Changes in household activity status between $t_{1}$ and $t_{2}$ : } \\
\hline Hhd inactive at $\mathrm{t}_{1}$ and $\mathrm{t} 2$ & 1 & & & 1 & & \\
\hline Hhd retired between $\mathrm{t}_{1}$ and $\mathrm{t} 2$ & 0.96 & 0.11 & -0.32 & $0.75^{*}$ & 0.10 & -1.85 \\
\hline Hhd still active at $\mathrm{t} 2$ & $0.73^{\dagger}$ & 0.12 & -1.95 & $0.70^{*}$ & 0.13 & -1.66 \\
\hline
\end{tabular}


Union transitions between $\mathrm{t} 1$ and $\mathrm{t} 2$ :

With same spouse/partner at tl and to

With spouse/partner at $\mathrm{t} 1$ but no spouse/partner at t2

With different spouse/partner at t2

With no spouse/partner at t1 but spouse/partner at t2

With no spouse/partner at $\mathrm{t} 1$ or at $\mathrm{t} 2$

1

$\begin{array}{llrlrr}2.11^{* * *} & 0.29 & 5.5^{1} & 0.65^{*} & 0.09 & -3.86 \\ 1.15 & 0.30 & 0.53 & 1.91^{*} & 0.48 & 2.36 \\ 0.73 & 0.24 & -0.95 & 1.93^{*} & 0.44 & 1.73 \\ 1.87^{* * *} & 0.26 & 4.59 & 0.69^{*} & 0.08 & -4.61\end{array}$

Children leaving between $\mathrm{t}_{1}$ and $\mathrm{t} 2$ :

No children at $\mathrm{t} 1$ or at $\mathrm{t} 2$

All children left between $\mathrm{t} 1$ and $\mathrm{t} 2$

Child/ren living with parents at $\mathrm{t} 2$

Constant

$\mathrm{N}$

1.22

o. $61 * *$

$0.06 * * *$

3,549

Housing tenure at tI: social renting:

Gender:

Male (Ref.)

Female

1

1.00

0.17

$-0.02$

1.07

0.2

0.37

1

55-59 (Ref.)

$60-64$

$65-69$

1.29

1.02

0.25

0.24

1.32

0.07

1

0.72

$0.16-1.34$

0.17

$-1.37$

Educational qualification at $\mathrm{t} 1$ :

No post-secondary education (Ref.)

Post-secondary education

Social class at $\mathrm{t} 1$ :

In employment - professional/managerial (Ref.)

In employment - skilled

In employment - partly/un-skilled

Never worked in the last 10 years
0.65

0.30

0.74

1.06

$2.05 * *$
$-0.93$

2.00

0.82

1.70

$0.23-0.94$

1.21

1

$0.21 \quad 0.29$

$\begin{array}{ll}0.54 & 2.75\end{array}$ 


\begin{tabular}{|c|c|c|c|c|c|c|}
\hline & \multicolumn{3}{|c|}{ Downsizing } & \multicolumn{3}{|c|}{ Upsizing } \\
\hline & Relative risk ratio & $\mathrm{SE}$ & $z$-score & Relative risk ratio & $\mathrm{SE}$ & $z$-score \\
\hline Number of rooms at $\mathrm{t}_{1}$ & $6.74^{* * *}$ & 0.96 & $13 \cdot 44$ & $0.26 * * *$ & 0.03 & -10.25 \\
\hline $\begin{array}{l}\text { Changes in health status between } t_{1} \text { and t2: } \\
\text { None in the hhd with LLTI at } t_{1} \text { or at } \mathrm{t}_{2} \\
\text { At least } 1 \text { in the hhd developed LLTI between t } 1 \text { and t2 } \\
\text { At least } 1 \text { in the hhd with LLTI at t } 1\end{array}$ & $\begin{array}{l}1 \\
1.90^{*} \\
1.44\end{array}$ & $\begin{array}{l}0.54 \\
0.35\end{array}$ & $\begin{array}{l}2.27 \\
1.5^{1}\end{array}$ & $\begin{array}{l}1 \\
1.09 \\
0.78\end{array}$ & $\begin{array}{l}0.32 \\
0.19\end{array}$ & $\begin{array}{r}0.28 \\
-0.99\end{array}$ \\
\hline $\begin{array}{l}\text { Changes in household activity status between } t_{1} \text { and } \mathrm{t}_{2} \text { : } \\
\text { Hhd inactive at } \mathrm{t} 1 \text { and } \mathrm{t} 2 \\
\text { Hhd retired between } \mathrm{t} 1 \text { and } \mathrm{t} 2 \\
\text { Hhd still active at } \mathrm{t} 2\end{array}$ & $\begin{array}{l}1 \\
1.05 \\
0.93\end{array}$ & $\begin{array}{l}0.23 \\
0.34\end{array}$ & $\begin{aligned} & 0.21 \\
- & 0.2\end{aligned}$ & $\begin{array}{l}1 \\
0.94 \\
1.02\end{array}$ & $\begin{array}{l}0.22 \\
0.39\end{array}$ & $\begin{array}{r}-0.26 \\
0.06\end{array}$ \\
\hline $\begin{array}{l}\text { Union transitions between } \mathrm{t} 1 \text { and } \mathrm{t} 2 \text { : } \\
\text { With same spouse/partner at } \mathrm{t} 1 \text { and } \mathrm{t} 2 \\
\text { With spouse/partner at } \mathrm{t} 1 \text { but no spouse/partner at t2 } \\
\text { With different spouse/partner at } \mathrm{t} 2 \\
\text { With no spouse/partner at } \mathrm{t} 1 \text { but spouse/partner at t2 } \\
\text { With no spouse/partner at } \mathrm{t} 1 \text { or at } \mathrm{t} 2\end{array}$ & $\begin{array}{l}1 \\
2.06 * * \\
1.37 \\
0.70 \\
2.57^{* * *}\end{array}$ & $\begin{array}{l}0.54 \\
0.72 \\
0.34 \\
0.55\end{array}$ & $\begin{aligned} & 2.76 \\
& 0.6 \\
- & 0.75 \\
& 4.42\end{aligned}$ & $\begin{array}{l}1 \\
0.64 \\
2.22 \\
2.03^{\dagger} \\
0.4^{* * *}\end{array}$ & $\begin{array}{l}0.19 \\
1.14 \\
0.83 \\
0.1\end{array}$ & $\begin{array}{r}-1.4^{6} \\
1.55 \\
1.73 \\
-3.5^{1}\end{array}$ \\
\hline $\begin{array}{l}\text { Children leaving between } \mathrm{t} 1 \text { and } \mathrm{t} 2 \text { : } \\
\text { No children at } \mathrm{t} 1 \text { or at } \mathrm{t} 2 \\
\text { All children left between } \mathrm{t} 1 \text { and } \mathrm{t} 2 \\
\text { Child/ren living with parents at } \mathrm{t} 2\end{array}$ & $\begin{array}{l}1 \\
0.53^{*} \\
0.16 * * *\end{array}$ & $\begin{array}{l}0.14 \\
0.05\end{array}$ & $\begin{array}{l}-2.3^{6} \\
-5.87\end{array}$ & $\begin{array}{l}1 \\
1.10 \\
4.16^{* * * *}\end{array}$ & $\begin{array}{l}0.3^{8} \\
1.14\end{array}$ & $\begin{array}{l}0.27 \\
5.20\end{array}$ \\
\hline $\begin{array}{l}\text { Constant } \\
\mathrm{N}\end{array}$ & $\begin{array}{l}0.00 * * * \\
1,190\end{array}$ & 0.35 & -11.82 & $99.93^{* * *}$ & $57 \cdot 4^{8}$ & 8.00 \\
\hline
\end{tabular}

Notes: SE: standard error. Ref.: reference category. t1: time 1 (2001). t2: time 2 (2011). hhd: household. LLTI: limiting long-term illness. Source: Authors' analysis of the Scottish Longitudinal Study.

Significance levels: $\dagger p<0.10, * p<0.05,{ }^{* *} p<0.01, * * * p<0.001$. 
Results are presented as relative risk ratios (i.e. the risk of upsizing/downsizing relative to the risk of moving to same-size housing) and expressed net of the effects of the demographic and socio-economic variables.

Owner-occupiers in $200 I$. The statistical analysis on the determinants of a residential move identified poor health as one of several possible triggers for a residential move. Movers from owner-occupied households where at least one member already had a limiting long-term illness in 2001 are also more likely to downsize (and less likely to upsize) by 2011 compared to those in good health. This result is expected, given the greater practical burden of a larger home. Contrary to what might be expected, however, a deterioration in health during the decade is not associated with adjustments in housing consumption.

Retirement from the labour force is another change which is associated with the decision to relocate. However, we find that owner-occupier households which become inactive during the decade are not significantly more inclined to downsize, although they are less likely to upsize, compared to households which are already economically inactive at the start of the decade. Those where at least one spouse/partner is still economically active are also less likely to alter their housing size.

It is possible that other household and personal changes influence the housing adjustments of older home-owners in Scotland. As our analysis of residential moves demonstrates, union transitions often prompt a decision to relocate. It might be expected that older movers would be more inclined to downsize their housing if they experience bereavement or divorce, thus adjusting housing consumption in response to smaller household size and, possibly, reduced financial resources. This is confirmed by the results reported in Table 5, which show that older movers who experience the end of their marital union/partnership are significantly more likely to move to a smaller house than those who do not. More generally, the absence of a spouse/partner, either from the start of the period or following the dissolution of the union during the decade, is associated with higher risks of downsizing. Conversely, risks of upsizing are significantly lower. (Re-) partnering during the decade, on the other hand, is significantly associated with a higher likelihood of moving to a larger house.

Household size also declines as children leave the parental home, and this might be expected to prompt downsizing among older adults, although in this case the financial burden on the household may actually decrease. Our results confirm that the presence, or absence, of children in the household is a major driver of housing adjustments among older movers. Compared to those who already had no co-residing children at the start of the period, those (still) living with their children at the end of the 
decade are less likely to downsize and more likely to upsize. Further, and unexpectedly, those whose children leave during the decade are also more likely to upsize, although the result is only marginally significant.

Social renters in $200 \mathrm{O}$. The analysis on movers who were in social rented housing at time 1 also reveals the importance of household circumstances and their changes as key triggers of housing adjustments, albeit with some qualifications. First, housing adjustments are not significantly associated with an older individual or their spouse/partner having a limiting longterm illness at the start of the decade, but a deterioration in health during the decade does prompt a move to smaller housing. Second, there is no evidence that household activity status - or its changes during the decade-influences the housing consumption of social renters. Third, while the absence or the loss of a spouse/partner is also significantly associated with a move to smaller housing among social renters, we do not observe the same effect of (re-)partnering on the likelihood of moving to larger housing as we do for owner-occupiers. Although social renters who are not living with a partner in 2001 but are by 2011 appear to be more likely to upsize their housing, the effect is only marginally significant, and there is no association for those who change partners between the two dates. For social renters, it is the presence of children in the household that is a major driver of housing consumption, reducing the likelihood of downsizing and considerably increasing that of upsizing.

In sum, our findings suggest that household circumstances and their changes play a significant role in triggering the adjustments in housing consumption of all older movers. Housing adjustments, however, also respond to older movers' initial characteristics. In particular, educational level and social class differentiate the risks of downsizing or upsizing for owner-occupiers, whereas initial housing size affects the likelihood of housing changes for social renters.

\section{Discussion}

This paper contributes to the understanding of adjustments in housing consumption in later life by investigating the role of important lifecourse transitions experienced by older individuals and their households, namely changes in health, retirement, union transition and the departure of adult children from the parental household. It recognises the diversity of housing outcomes among older adults by examining separately whether owner-occupiers and social renters adjust their housing size by moving to either larger or smaller accommodation in response to similar changes in 
their personal and household circumstances. The focus is on Scotland, a country where a rapidly ageing population has the potential to affect intergenerational interdependencies in housing consumption.

The study shows that, although the majority of older adults in Scotland do not change their place of residence during the study decade, for the minority who do move, all four lifecourse transitions are significant triggers for residential relocation. Nevertheless, not all older movers follow a similar housing trajectory: while the majority downsize their housing, a significant proportion upsize to larger homes, and a larger proportion of social tenants compared to owner-occupiers move to housing of the same size. Further, there is considerable diversity across the two major tenure groups in the associations between household changes and housing consumption adjustments. In the remainder of this section we discuss the role of each household change in influencing both residential moves and housing adjustments during the ten years after 2001 in order to explore this diversity in more detail.

Existing literature on residential mobility at older ages emphasises how changes in family structure, financial resources and physical needs create a gap between the desired and the current housing consumption which may prompt a decision to relocate. Although increasing diversity in the sequencing and timing of lifecourse events implies that these changes cannot be tied to a specific age (Elder, Johnson and Crosnoe 2003; Geist and McManus 2008; Sanders and Bell 2014), migration rates are usually found to be highest in late middle age, around the time of retirement, and then increase again after age 8o, when health deteriorates to such an extent that older individuals move to institutional settings (Evandrou, Falkingham and Green 2010; Litwak and Longino 1987; Rogers 1988). Our study is not designed to reflect the later peak in health-related mobility, as we only observe individuals up to age 79, and, most importantly, we focus on moves from and to private households. Further, our analyses might be under-estimating health-related mobility, as we only follow individuals enumerated at both censuses, thus selecting out older adults who died during the decade and who are thus more likely to have experienced poor health. Nevertheless, health-related moves might occur even at an earlier stage, when moderate forms of disability do not necessitate a move to an institution and relocation to more suitable housing or closer to a kinship network is usually sufficient to cope with the challenges of deteriorating health (Glaser and Grundy 1998). This view is supported by our findings, which show that older adults in Scotland who report a limiting long-term illness, either at the start or through the decade, tend to be more likely to move house. Moreover, for older adults both in owner-occupied and in social rented housing, adjustments in housing consumption are 


\section{Francesca Fiori et al.}

consistent with the notion that smaller and more easily manageable housing might be preferable to larger housing for those in poorer health. In particular, having a limiting long-term illness at the start of the decade discourages a move to larger housing for home-owners, whereas a deterioration in health during the decade is associated with downsizing among social renters, possibly because those in poor health are usually given preference for a transfer to smaller (supported) housing.

A common experience individuals go through at older ages is that of retirement from the labour force, which typically affects the financial resources available to them and their household, often entailing a reduction in available wealth as pensions rarely compensate fully for the loss of employment income. As a consequence, households might be inclined to reduce housing consumption following retirement by moving to a smaller home. At the same time, for some, the payment of a lump sum on retirement might favour investment in larger housing, perhaps as a form of insurance for later-life needs (Ermisch and Jenkins 1999). The decision of whether or not to relocate around retirement might also be motivated by other, less directly financial considerations. Sanders and Bell (2014) rightly point out that retirement migration is not a purely individual decision, in that the timing of retirement-as well as that of the move - is often conditioned by a spouse/partner's retirement timing. This is especially important considering the increase in dual-earner couples over the past few decades (Blossfeld and Drobnic 2001). For such couples, it is only when both partners have retired that their place ties based upon labour force status are loosened (Longino et al. 20o8; Sanders and Bell 2014) and households may choose to improve their quality of life (Bonnet, Gobillon and Laferrère 2010). Our study shows that, in Scotland, households where spouses/partners (both, if present) become economically inactive during the decade are significantly more likely to relocate compared with households already inactive at the beginning of the decade. This suggests that the 'retirement' moves of older adults are time-sensitive and that those who do not move soon after retirement tend to stay put. The SLS data do not allow us to investigate this further but the relative timing of residential moves and household changes could usefully be explored in future research.

For those who do move, and contrary to our expectations, changes in the household's activity status do not appear to encourage adjustments in housing consumption among older movers. Nevertheless, it should be noted that opportunities to adjust housing consumption after retirement do vary by tenure group. Among older adults in social rented housing, a large majority was already inactive at the start of the decade, so that fewer of them experience the transition out of the labour force during the 
decade. Further, a change in the tenants' activity status does not give them priority to obtain a housing transfer. A larger proportion of home-owners, on the other hand, experience the transition to retirement during the decade. Further, the benefits of adjusting housing consumption - as well as the freedom to do so - following the revision of their finances after retirement might be greater than for social tenants. However, in line with previous studies (Venti and Wise 1989, 1990, 2001), we find no evidence that older home-owners in Scotland seek to reduce housing wealth to increase current consumption, nor do we find a wealth effect, as they are less likely to upsize if the household retires during the decade. It may be suspected that the adjustment of housing consumption in response to changed financial circumstances following retirement occurs through other adjustment strategies, such as moves to a less-expensive housing market, but further analyses (not shown) find no association between the housing adjustments of older movers and house prices in local housing markets. Factors other than purely economic considerations may therefore be more important as drivers of housing adjustments among older adults in the owner-occupied sector in Scotland.

The idea that the loss of a spouse/partner - either through bereavement or divorce - encourages the decision to relocate and adjust housing is also a recurrent theme in the literature on residential mobility in later life. Bonnet, Gobillon and Laferrère (2010) provided an extensive review of the main mechanisms by which the death of a spouse can affect the residential mobility of survivors, as well as their housing and location choices: surviving spouses move to adjust their dwelling to the income loss due to widowhood and to their current or anticipated need for care. Downsizing usually reduces maintenance tasks, as smaller housing units are easier to manage than larger houses; renting accommodation has a similar advantage compared to home-ownership. Living closer to a child or in a larger settlement is also seen as a way of facilitating access to social support and care following the loss of a spouse. Drawing on existing literature (Angelini and Laferrère 2012; Bonnet, Gobillon and Laferrère 2010; Evandrou, Falkingham and Green 2010; Uren and Goldring 2007), we investigate whether union transitions - in our sample mostly through the death of a partner - also act as an important trigger of adjustments in housing consumption at older ages in Scotland. Results from the empirical analyses are consistent with the tendency among older people to move following the loss of a spouse/partner in order to accommodate new locational and/or housing preferences. Further, in both tenure groups, older movers do adjust their housing consumption after union dissolution, with the loss of a spouse/partner strongly associated with a greater likelihood of downsizing. In addition, and following recommendations by Evandrou, 
Falkingham and Green (2010), we extend the scope of previous research to cover other, albeit still rare, union transitions, such as (re-)partnering. For older movers in owner-occupation, forming a new union is associated with a move to larger housing, reflecting the greater purchasing power of a couple compared with a single person. The association is weaker and restricted to those who were unpartnered in 2001 for those in the social rented sector, where allocation policies typically treat single persons and couples as having similar space requirements.

The final change we investigate concerns the effect of the departure of all children from the household on the housing choices of older parents. A common expectation is that, because household size declines as children leave home, the departure of the last child should induce households to reduce their housing consumption and move to a smaller home (Banks et al. 2012). The presence of empty space in the house will add further emotional pressure, emphasising the need to downsize, although any resultant diminution in parents' financial burden might be expected to have the opposite effect. For some households, this could enable a lifestyle-oriented move to optimise local amenities and/or social networks, irrespective of housing size. Other older home-owners might be inclined to increase housing consumption in order to maximise wealth for use in later life (Jarvis 2008; Smith and Searle 2006), although in the context of rising house prices in all areas of Scotland this strategy could require considerable additional investment. Given historically high house prices, parental housing wealth may instead be directed to helping adult children gain a foothold on the housing ladder. Parents may thus choose to downsize in order to support their children in higher education or, indeed, facilitate their access to home-ownership (Banks et al. 2010; Hamnett 2012).

Our findings for Scotland show that households in which all children leave home during the decade are significantly more likely to change their place of residence, whereas older adults with co-resident children are less likely to relocate compared to households with no children. For both tenure groups, housing consumption is also strongly dependent upon the presence of adult children in the household, as older adults with co-resident children are significantly less likely to downsize and more likely to upsize. The effect of a transition to an 'empty nest' is less clear. For owner-occupiers, results are inconclusive as they point to both a downward and an upward revision of housing size, and the relationships are not statistically significant. For social tenants, the negative effect on downsizing-unexpected given the importance of household size as a criterion for allocating social housing - might reflect a lag between a house move and the departure of children. Some moves may be associated with a change of tenure to owner-occupation, which significantly increases the 
likelihood of upsizing. Again, the data do not allow us to establish the relative timing of these events, but this unexpected finding is worthy of more detailed research into how older adults negotiate the social housing sector in Scotland.

Overall, our empirical findings indicate that certain changes in household circumstances act as important prompts to moving house and adjusting housing size. Household transitions influence residential moves in similar ways for the two tenure groups, but their association with adjustments in housing consumption varies according to housing tenure. In order to understand housing consumption trajectories at older ages fully, we must also acknowledge the importance of constraints placed on housing and location choices, and the disincentives to residential mobility. For home-owners, moving house is a costly process both in financial and psychological terms. Mobility constraints, available resources or individual preferences might prevent older households from moving. For social tenants, eligibility and supply factors play a greater role than individual preferences and aspirations, as residential mobility within the sector is regulated by needs-based policies that allocate housing to households meeting certain criteria.

Unsurprisingly, movers in the two tenure groups also differ insofar as their socio-economic resources affect the likelihood of adjusting housing consumption. The risks of downsizing or upsizing for owner-occupiers vary by education and social class, whereas the likelihood of housing changes for social renters is more dependent on initial housing size than socio-economic characteristics, reinforcing the notion that preferences and constraints play different roles in the housing behaviour of the two tenure groups. Higher socio-economic status allows greater choice for purchasers in the housing market. In accordance with the notion of an increasingly de-standardised lifecourse, it appears that, for some among this prebaby boom generation in Scotland, greater wealth is extending the scope for making individualised choices in later life.

\section{Conclusions}

Previous studies on migration at older ages have documented its strong association with household changes, with certain life events acting as important triggers prompting a move. Our study confirms the role of changes in both personal and household circumstances not only as influences on residential moves at older ages in Scotland, but also, although in different ways, as influences on adjustments in housing consumption. In the latter case, it is not retirement but children leaving home and the consequent reduction 
in household size that appears to be of particular importance as a driver of downsizing.

While this study is able to track individual households from one census to the next and thus to examine decadal change in place of residence in some detail, limitations imposed by the data have also been recognised. We are not able to determine either the relative timing of household transitions and residential moves nor the number of moves that the household made during the ten-year period. It is thus possible that households classified in the study as downsizing had moved to similar-sized housing, or even upsized, at some point between 2001 and 2011 . More detailed longitudinal data with full migration histories would be needed to investigate this possibility, as well as to draw firm conclusions on the causal direction of the relationships between household changes and housing transitions. Moreover, only changes of address across different unit postcodes are counted as moves. As a result, our data might underestimate the number of moves undertaken by older adults in Scotland. Nevertheless, the SLS has the advantage over other sample surveys of providing a large-scale data set representative of the Scottish population as a whole, thus making it possible to obtain reliable estimates for relatively rare events such as the housing adjustments of older movers.

Scotland may be unique within the UK in that, historically, it had a larger proportion of local authority housing than the other constituent countries, especially in its major cities. Despite the sale of social housing under the right-to-buy legislation introduced over three decades ago, this history still resonates in contemporary urban housing markets which tend to be socially segmented. Thus, although the present study shows that older adults in Scotland respond to household changes in similar ways to older adults in other parts of the UK, future research could usefully examine the geographies of residential moves and housing adjustments in more detail. Further, the dramatic but spatially differentiated increases in house prices between 2001 and the economic crisis of $2007-08$ have resulted in young adults facing considerable difficulties getting on to the housing ladder. They are, therefore, staying longer in the parental home and our findings suggest that a likely outcome is that older parents will be less inclined to move house, and less inclined to downsize their housing if they do move, until all children have left the family home. Moreover, any reduction in the residential mobility of older households is likely to exacerbate the difficulties faced by younger adults. This study thus raises concerns over the inter-dependencies between younger and older generations in the housing market and lays the groundwork for further research on the housing moves and adjustments of older adults in Scotland. 


\section{Acknowledgements}

The help provided by staff of the Longitudinal Studies Centre - Scotland (LSCS) is acknowledged. The LSCS is supported by the Economic and Social Research Council (ESRC)/JISC, the Scottish Funding Council, the Chief Scientist's Office and the Scottish Government. The authors alone are responsible for the interpretation of the data. Census output is Crown copyright and is reproduced with the permission of the Controller of HMSO and the Queen's Printer for Scotland. This research was funded by ESRC Secondary Data Analysis Initiative (grant number $\mathrm{ES} / \mathrm{KoO} 3747 / 1$ ). The study is based solely on the analysis of anonymised secondary data. The research team abided by the strict rules governing access to the SLS and the paper was cleared for publication by the SLS Project Manager. Outputs are presented in aggregate form and no information on individuals or individual households is disclosed. The study does not involve human participants or interaction with vulnerable population groups. The research was granted ethical approval by UTREC, the University of St Andrews' Ethics Committee.

\section{NOTES}

1 SLS members living in complex households either at time 1 or at time 2 (i.e. with more than one nuclear family and/or unrelated individuals) are excluded from our empirical analyses due to definitional uncertainties about the direction of changes in housing consumption.

2 Postcodes are structured hierarchically, supporting four levels of geographical units: postcode areas, postcode districts, postcode sectors and unit postcodes. Unit postcodes are thus the smallest geographical unit. According to the 2011 Census estimates (National Records of Scotland 2013), a unit postcode has on average -20 households or a total of 40 usual residents (although some of the largest unit postcodes may include up to 100 households).

3 At both censuses, the definition of a room does not include bathrooms, toilets, halls or landings, or rooms that can only be used for storage. All other rooms, e.g. kitchens, living rooms, bedrooms, utility rooms, studies and conservatories are counted.

4 Because the variable is derived by comparing the de facto partnership status of SLS members at census dates, we cannot distinguish between union transition occurring because of a separation/divorce or because of the death of a partner. However, we know that, for individuals who were legally married at time 1, divorce is a rare event as less than 2 per cent of them experienced separation/ divorce during the decade. As legally married older adults represent the large majority (more than 95\%) of older adults living with a spouse/partner at time 1, we can assume that the partner's death constitutes the most frequent cause for the end of a partnership at this age.

5 To define social class we used an SLS variable which is derived by combining information on individuals' employment status and on their occupation coded according to the Standard Occupational Classification 1990. The variable provided by the SLS has the following categories: Professional; Managerial and technical; Skilled non-manual; Skilled manual; Partly skilled; Unskilled; Armed Forces; Over 74 or person who never worked; Missing. 


\section{Francesca Fiori et al.}

6 The variable 'place of residence' is based on the Scottish Government urbanrural classification, which defines: large urban areas as settlements of 125,000 or more people; other urban areas as settlements of 10,000-124,999 people; small towns as settlements of $3,000-9,999$ people; rural areas as areas with a population of less than 3 ,ooo people.

\section{References}

Agresti, A. 2013. Categorical Data Analysis. Third edition, Wiley, New York.

Al-Hamad, A., Flowerdew, R. and Hayes, L. 1997. Migration of elderly people to join existing households: some evidence from the 1991 household sample of anonymised records. Environment and Planning A, 29, 7, 1243-55.

Angelini, V. and Laferrère, A. 2012. Residential mobility of the European elderly. CESifo Economic Studies, 58, 3, 544-69.

Banks, J., Blundell, R., Oldfield, Z. and Smith, J. P. 2010 . Housing price volatility and downsizing in later life. In Wise, D. A. (ed.) Research Findings in the Economics of Ageing. University of Chicago Press, Chicago, 337-79.

Banks, J., Blundell, R., Oldfield, Z. and Smith, J.P. 2012. Housing mobility and downsizing at older ages in Britain and the USA. Economica, 79, 313, 1-26.

Beer, A. and Faulkner, D. 2011. Housing Transitions Through the Life Course: Aspirations, Needs and Policy. Policy Press, Bristol, UK.

Blossfeld, H.-P. and Drobnic, S. 2001. Careers of Couples in Contemporary Society: From Male Breadwinner to Dual-earner Families. Oxford University Press, Oxford.

Bonnet, C., Gobillon, L. and Laferrère, A. 2010. The effect of widowhood on housing and location choices. Journal of Housing Economics, 19, 2, 94-108.

Boyle, P.J., Feijten, P., Feng, Z., Hattersley, L., Huang, Z., Nolan, J. and Raab, G. 2009. Cohort profile: the Scottish Longitudinal Study (SLS). International Journal of Epidemiology, 38, 2, 385-92.

Clark, W. A. V., Deurloo, M. and Dieleman, F. 2006. Residential mobility and neighbourhood outcomes. Housing Studies, 2 1, 3, 323-42.

Coulter, R., van Ham, M. and Findlay, A. M. 2016. Re-thinking residential mobility: linking lives through time and space. Progress in Human Geography, 4o, 3, 352-74.

Elder, G. H., Johnson, M. K. and Crosnoe, R. 2003. The emergence and development of life course theory. In Mortimer, J. T. and Shanahan, M.J. (eds) Handbook of the Life Course. Kluwer Academic/Plenum Publishers, New York, 3-19.

Ermisch, J. F. and Jenkins, S. P. 1999. Retirement and housing adjustment in later life: evidence from the British Household Panel Survey. Labour Economics, 6, 2, 311-33.

Evandrou, M., Falkingham, J. and Green, M. 2010. Migration in later life: evidence from the British Household Panel Survey. Population Trends, 141, Autumn 2010, 77-94.

Findlay, A. M., McCollum, D., Coulter, R. and Gayle, V. 2015. New mobilities across the life course: a framework for analysing demographically linked drivers of migration. Population, Space and Place, 21, 4, 309-402.

Ford, R. 1993. The process of mobility decision-making in later old age: early findings from an original survey of elderly people in south east England. Espace, Populations, Sociétés, 11, 3, 523-32.

Forrest, R. 1987. Spatial mobility, tenure mobility and emerging social divisions in the UK housing market. Environment and Planning A, 19, 12, 1611-30. 
Geist, C. and McManus, P. A. 2008. Geographical mobility over the life course: motivations and implications. Population, Space and Place, 14, 4, 283-303.

Glaser, K. and Grundy, E. 1998. Migration and household change in the population aged 65 and over, 1971-1991. International Journal of Population Geography, 4, 4, $323-39$.

Hamnett, C. 2012. Housing wealth and inheritance in the United Kingdom. In Smith, S.J. (ed.), International Encyclopaedia of Housing and Home. Elsevier Science, Oxford, 679-84.

Jarvis, H. 2008. Doing deals on the house in a 'post-welfare' society: evidence of micro-market practices from Britain and the USA. Housing Studies, 23, 2, 21 3-31.

Kendig, H. 1984. Housing careers, life cycle and residential mobility, implications for the housing market. Urban Studies, 21, 3, 271-83.

Litwak, E. and Longino, C. F. 1987. Migration patterns among the elderly: a developmental perspective. The Gerontologist, 27, 3, 266-72.

Longino, C. F., Bradley, D. E., Stoller, E. P. and Haas, W. H. 20o8. Predictors of nonlocal moves among older adults: a prospective study. Journals of Gerontology: Social Science, $\mathbf{6}_{3} \mathbf{B}, 1, \mathrm{~S}_{7}-14$.

Luborsky, M. R., Lysack, C. L. and Van Nuil, J. 2011 . Refashioning one's place in time: stories of household downsizing in later life. Journal of Aging Studies, 25, 3, $243-52$.

Morris, E. W. and Winter, M. 1975. A theory of family housing adjustment. Journal of Marriage and the Family, 37, 1, 79-88.

Mulder, C. H. and Hooimeijer, P. 1999. Residential relocations in the life course. In van Wissen, L. J. G. and Dykstra, P. (eds), Population Issues. An Interdisciplinary Focus. Kluwer Academic/Plenum Publishers, New York, 159-86.

National Records of Scotland 2013. Statistical Bulletin. 20 I I Census: Population and Household Estimates for Scotland. Release 1 C (Part Two). Available online at http:// www.scotlandscensus.gov.uk/documents/censusresults/release 1c/relıc2sb.pdf [Accessed o1 March 2017].

National Records of Scotland 2015. Statistical Bulletin. 20 I I Census: Population and Household Estimates for Scotland. Release 3 N. Available online at http://www.scotlandscensus.gov.uk/news/census-20 1 1-release-3n-detailed-characteristics-scotlands-population [Accessed o1 March 2017].

Payne, J. and Payne, G. 1977. Housing pathways and stratification; a study of life chances in the housing market. Journal of Social Policy, 6, 2, $125^{-} 5^{6 .}$

Pickvance, C. 1974. Life cycle, housing tenure and residential mobility: a path analytic approach. Urban Studies, 1 1, 2, 1 $71-88$.

Rabe, B. and Taylor, M. 2009. Residential mobility, neighbourhood quality and life course events. ISER Working Paper Series 2009-28, Institute for Social and Economic Research, Essex, UK.

Rogers, A. 1988. Age patterns of elderly migration: an international comparison. Demography, 25, 3, 355-70.

Rossi, P. 1955. Why Families Move. Free Press, Glencoe, Illinois.

Sanders, N. and Bell, M. 2014 . Migration and retirement in the life course: an event history approach. Journal of Population Research, 31, 1, 1-27.

Scottish Government 2001. Housing (Scotland) Act. Housing lists and allocations. SEDD Circular 1/2002, Scottish Executive Development Department, Edinburgh.

Smith, S. and Searle, B. 20o6. Dematerialising money? Observations on the flow of wealth from housing to other things. Housing Studies, 23, 1, 21-43.

Tatsiramos, K. 2006. Residential mobility and housing adjustment of older households in Europe. IZA Discussion Paper 2345, Institute for the Study of Labor, Bonn, Germany. 


\section{Francesca Fiori et al.}

Uren, Z. and Goldring, S. 2007. Migration trends at older ages in England and Wales. Population Trends, 13o, Winter 2007, 31-40.

Venti, S. F. and Wise, D. A. 1989 . Aging, moving and housing wealth. In Wise, D. A. (ed.), The Economics of Aging. University of Chicago Press, Chicago, 9-48.

Venti, S. F. and Wise, D. A. 1990. But they don't want to reduce housing equity. In Wise, D. A. (ed.), Issues in the Economics of Aging. University of Chicago Press, Chicago, 13-32.

Venti, S.F. and Wise, D.A. 2001. Aging and housing equity: another look. In Wise, D. A. (ed.), Perspectives on the Economics of Aging. University of Chicago Press, Chicago, 127-80.

Accepted I 8 July 20I7; first published online I I September 2017

Address for correspondence:

Francesca Fiori,

ESRC Centre for Population Change - University of St Andrews (UK), Ladywell House, Ladywell Road, Edinburgh EH12 7 TF, UK

E-mail: ff2o@st-andrews.ac.uk 


\section{Appendix}

$\mathrm{T}$ A B L E A 1 . Logistic regression on the probability of a residential move

\begin{tabular}{|c|c|c|c|}
\hline & Odds ratio & $\mathrm{SE}$ & $z$-score \\
\hline \multicolumn{4}{|l|}{ Gender: } \\
\hline Male & 1 & & \\
\hline Female & $0.90^{* *}$ & 0.03 & -3.15 \\
\hline \multicolumn{4}{|l|}{ Age-class at t1: } \\
\hline $55^{-59}$ & 1 & & \\
\hline $60-64$ & $0.84^{* * *}$ & 0.03 & $-4 \cdot 5^{2}$ \\
\hline $65^{-69}$ & $0.69 * * *$ & 0.03 & -8.02 \\
\hline \multicolumn{4}{|l|}{ Educational qualification: } \\
\hline No post-secondary education & 1 & & \\
\hline Post-secondary education & $0.91^{*}$ & 0.04 & -2.09 \\
\hline \multicolumn{4}{|l|}{ Social class at tı: } \\
\hline In employment - professional/managerial & 1 & & \\
\hline In employment - skilled & $1.11^{*}$ & 0.05 & 2.33 \\
\hline In employment - partly/un-skilled & 0.98 & 0.04 & $-0.3^{6}$ \\
\hline Never worked in the last 10 years & $1.14^{*}$ & 0.07 & 2.19 \\
\hline \multicolumn{4}{|l|}{ Tenure and type of accommodation: } \\
\hline Home-owner - house & 1 & & \\
\hline Home-owner - flat & $1.87 * * *$ & 0.10 & 12.20 \\
\hline Social renting - house & 0.97 & 0.06 & $-0.5^{8}$ \\
\hline Social renting - flat & $2.44^{* * *}$ & 0.14 & $15 \cdot 5^{\mathrm{O}}$ \\
\hline Private renting/other & $4.80 * * *$ & $0.3^{6}$ & 20.90 \\
\hline Missing & $3.19^{* * *}$ & $0.4^{0}$ & 9.19 \\
\hline Number of rooms at $\mathrm{t} 1$ & $1.09 * * *$ & 0.01 & $7 \cdot 95$ \\
\hline \multicolumn{4}{|l|}{ Place of residence at $t 1$ : } \\
\hline Large urban areas & 1 & & \\
\hline Other urban areas & 0.94 & 0.04 & $-1.4^{8}$ \\
\hline Small town/villages & $0.84^{* *}$ & 0.04 & -3.25 \\
\hline Rural areas & 1.02 & 0.05 & 0.48 \\
\hline \multicolumn{4}{|l|}{ Changes in health status between $\mathrm{t}_{1}$ and $\mathrm{t} 2$ : } \\
\hline None in the hhd with LLTI at $\mathrm{t} 1$ or at $\mathrm{t} 2$ & 1 & & \\
\hline At least 1 in the hhd got LLTI between $\mathrm{t} 1$ and $\mathrm{t} 2$ & $1.14^{* *}$ & 0.05 & 2.98 \\
\hline At least 1 in the hhd with LLTI at $t 1$ & $1.22^{* * *}$ & 0.05 & 5.21 \\
\hline \multicolumn{4}{|l|}{ Changes in household activity status between t1 and t2: } \\
\hline Hhd inactive at $\mathrm{t} 1$ and $\mathrm{t} 2$ & 1 & & \\
\hline Hhd retired between $\mathrm{t} 1$ and $\mathrm{t} 2$ & $1.15^{* * *}$ & 0.05 & $3 \cdot 5^{\mathrm{O}}$ \\
\hline Hhd still active at t2 & 0.89 & 0.05 & -2.05 \\
\hline \multicolumn{4}{|l|}{ Union transitions between t 1 and t2: } \\
\hline With same spouse at t1 and t2 & 1 & & \\
\hline With spouse at $\mathrm{t} 1 \mathrm{but}$ no spouse at $\mathrm{t} 2$ & $1.67 * * *$ & 0.08 & 10.62 \\
\hline With different spouse at t2 & $1.27 * *$ & 0.11 & 2.83 \\
\hline With no spouse at t1 but spouse at t 2 & $4 \cdot 79 * * *$ & 0.55 & 13.66 \\
\hline With no spouse at t1 nor at t2 & $1.31 * * *$ & 0.06 & 6.05 \\
\hline \multicolumn{4}{|l|}{ Children leaving between $\mathrm{t}_{1}$ and $\mathrm{t} 2$ : } \\
\hline No children at $t_{1}$ or at $t_{2}$ & 1 & & \\
\hline All children left between $\mathrm{t} 1$ and $\mathrm{t} 2$ & 1.06 & 0.05 & 1.15 \\
\hline Child/ren living with parents at t2 & $0.70^{* * *}$ & 0.04 & $-6.4^{1}$ \\
\hline
\end{tabular}

Notes: $\mathrm{N}=27,092$. SE: standard error. t1: time 1 (2001). t2: time 2 (2011). hhd: household. LLTI: limiting long-term illness.

Source. Authors' analysis of the Scottish Longitudinal Study.

Significance levels: $* p<0.05, * * p<0.01, * * * p<0.001$. 